\title{
A mini review on the potential pharmacological properties, cultivation, and market value of edible Lentinus mushrooms (Polyporaceae)
}

\section{Phonemany $M^{1,2}$, Raghoonundon $\mathrm{B}^{1,2}$, Luangharn $\mathrm{T}^{1,2}$, Tang $\mathrm{SM}^{1,2,3}$, Hyde $\mathrm{KD}^{1,2}$ and Thongklang $\mathbf{N}^{1,2 *}$}

${ }^{I}$ Center of Excellence in Fungal Research, Mae Fah Luang University, Chiang Rai 57100, Thailand

${ }^{2}$ School of Science, Mae Fah Luang University, Chiang Rai 57100, Thailand

${ }^{3}$ Kunming Institute of Botany, Chinese Academy of Sciences Kunming 65201, China

Phonemany M, Raghoonundon B, Luangharn T, Tang SM, Hyde KD, Thongklang N. 2021 - A mini review on the potential pharmacological properties, cultivation, and market value of edible Lentinus mushrooms (Polyporaceae). Fungal Biotec 1(2), 49-64, Doi 10.5943/FunBiotec/1/2/4

\begin{abstract}
Lentinus is a saprobic genus consisting of many edible species. Some species are widely consumed and important for the commercial market. Lentinus species are mostly distributed in tropical and subtropical regions, and few species like growing in temperate regions. According to our literature reviews, some Lentinus species have high nutrient value, medicinal properties, biotechnological, and environmental applications due to their reported bioactivities. Lentinus can also be considered as an important part for the economy as they are edible. In this short review, potential pharmacological properties, cultivation methods and economical value of Lentinus species are provided.
\end{abstract}

Keywords - economic - edible mushrooms - fungus - lentoid - medicinal mushrooms.

\section{Introduction}

Lentinus Fr. is a genus of Polyporaceae, which was established with L. crinitus (L.) Fr. as the type species. (Corner 1981, Grand et al. 2011, He et al. 2019). There are 635 taxon names listed under Lentinus in the Index Fungorum (http://www.indexfungorum.org/). For a total of 55 species including asexual morphs (He et al. 2019). This genus is widely distributed, and many phylogenetic studies have been done to resolve the relationships among Lentinus species (Corner 1981, Grand 2004, Grand et al. 2011, Seelan 2015, Seelan et al. 2015, Senthilarasu 2015). Corner (1981) defined the genus Lentinus different from other related genera by having skeleton-binding hyphae, and the genus mostly relates to Polyporus. Later Pegler (1983) published an extensive monograph of Lentinus as a polyphyletic and there are two subgenera of Lentinus sensu are Lentinus subg. Lentinus and Lentinus subg. Panus, which they separate is based on different hyphal systems and hymenophoral trama (Pegler 1983). However, Lentinus has widely document taxonomically controversial (Hibbett \& Vilgalys 1991, Pegler 1983, Binder et al. (2005, 2013), Seelan et al. 2015).

Lentinus was confused in previous taxonomic classification in groups of lentinoid and pleurotoid, which were Heliocybe Redhead \& Ginns, Lentinus Fr., Lentinula Earle, Lentinellus P. Karst., Neolentinus Redhead \& Ginns, Panellus P. Karst., Panus Fr., Pleurotus (Fr.) P. Kumm. (Donk 1964, 
Corner 1981, Pegler 1983, Singer 1986). The lentinoid characteristics distinctively have an eccentric to the central stipe attachment, decurrent gills, a tough and consistency basidome when compared to pleurotoid. Pleurotoid characteristics have fleshy and soft consistency basidome, and lateral to central attachment (Seelan et al. 2015), and their macro-morphology are provided in Fig. 1. Lentinus belongs to the lentinoid group because their main macro-characters are often fibrillose to squamulose on pileus and not split longitudinally when mature, decurrent lamellulae and usually serrulate to serrate lamellae edge, pores are present in some species e.g. L. arcularius (Batsch) Zmitr. and L. brumalis (Pers.) Zmitr., variable in stipe, absent annulus or present in L. sajor-caju (Fr.) Fr., absent volva. For microcharacters, they have hyphae pegs in most species and white oblong to cylindrical spores (Corner 1981, Largent 1986). It is widely distributed in both tropical and temperate regions, but the abundant species are present in tropical countries (Kirk et al. 2008, Seelan 2015). All species of Lentinus are known as wood decomposers playing an important role in the natural biological community of interacting organisms and their physical environment. They typically grow on fallen tree trunks, decaying wood, and old stumps. Lentinus basidiomes are soft when young and become leathery when matured. They are usually suitable for consumption when 3-5 days young. In Thailand, they can be found in the wet season from June to September, and some dry materials can stick on substrate throughout the year (Jonathan \& Fasidi 2001, Gbolagade et al. 2006, Sysouphanthong et al. 2010).

\section{Biological activities}

Mushroom species have been consumed by humans for thousands of years because of their good taste and unique flavors (Valverde et al. 2015, Roncero-Ramos \& Delgado-Andrade 2017). Mushroom species have high nutritional value as well as medicinal properties, and they can reduce the risks and treat certain diseases (Oyetayo 2011, Qin et al. 2015, Valverde et al. 2015, Lau \& Abdullah 2017, Fernandes et al. 2021). Lentinus species are edible mushrooms that could offer several important medicinal compounds, and studies on the genus are becoming widespread, which gives a practical exhibition and explanation. Therefore, bioactive compounds and biological activities of Lentinus species have received much attention in recent years because of the increasing interest in human health, and they have been studied in vitro and in vivo by many researchers, and interesting studies are provided in Table 1. Several studies have been showing Lentinus species exhibiting antioxidant (Dulay et al. 2015, Sevindik 2018); antibacterial and antitumor (López-Legarda et al. 2020); and antiviral, immune-modulating and cholesterol-regulating effects (Dulay et al. 2015). Lentinus polychrous Lév. is an edible species consumed by Thai local communities. It was analyzed phytochemical contents and bioactivities, its hot water-extracted polysaccharide fractions that can be protective activity on the viral and stronger than Ganoderma lucidum (Curtis) P. Karst (Fangkrathok et al. 2013, 2021). In addition, protein-based pharmaceutical products were considered to be one of the major new categories of medicine, and the soluble protein fraction of L. tigrinus was considered to be a potent anti-cancer compound. However, these compounds are not yet completely isolated and identified for the active single proteins or peptides (Mohammadnejad et al. 2019). Furthermore, Lentinus crinitus (L.) Fr. was found to have high ligninolytic and antioxidant activities, and the development of its lithium-enriched mycelial biomass could be used as an alternative functional food (Adenipekun \& Isikhuemhen 2008). Phenolic function as reducing agents of cancer and other human diseases (Anantharaju et al. 2016), which it was observed that L. squarrosulus Mont. contained $18.7 \mathrm{~g} / 100 \mathrm{~g}$ of phenolic acids (Ghasemzadeh \& Ghasemzadeh 2011, Ao \& Deb 2019).

\section{Nutritional value}

Mushrooms have high nutrient value included protein, carbohydrate minerals and vitamins. Their nutritional contents can be compared with the foods such as egg, milk (Akyüz \& Kirbağ 2010, Enas et al. 2016, Ho et al. 2020, Niego et al. 2021); and the details are shown in Fig. 2. The nutritional value index of mushrooms is 6 to 31 (Ferdousi et al. 2019), and it varies depending on species, their 
environment, condition and substrates supplied for mushroom cultivation (Carrasco et al. 2018, Chang $\&$ Wasser 2017). A commercial strain of Lentinus has been used for nutritional and medicinal purposes. For instance; five commercial species of Lentinus species such as L. conatus, L. cladopus, $L$. sajor-caju, L. squarrosulus and L. torulosus, and were analyzed for sugars, fatty acids, ascorbic acid, carotenoids, lycopene, phenolic compounds and amino acids (Atri 2014). There are many studies that have been analyzing the nutritional composition of Lentinus species as showed in Table 2. Lentinus has good medicinal properties, and also nutritional values such as high content of proteins, carbohydrates, low amounts of fat, vitamins, carotenoids and minerals (P, K, Mn, Ni, and $\mathrm{Fe}$ ) (Singdevsachan et al. 2013, Lau \& Abdullah 2017). Consequently, Lentinus could potentially be a wealthy source of nutritional and medicinal compounds.
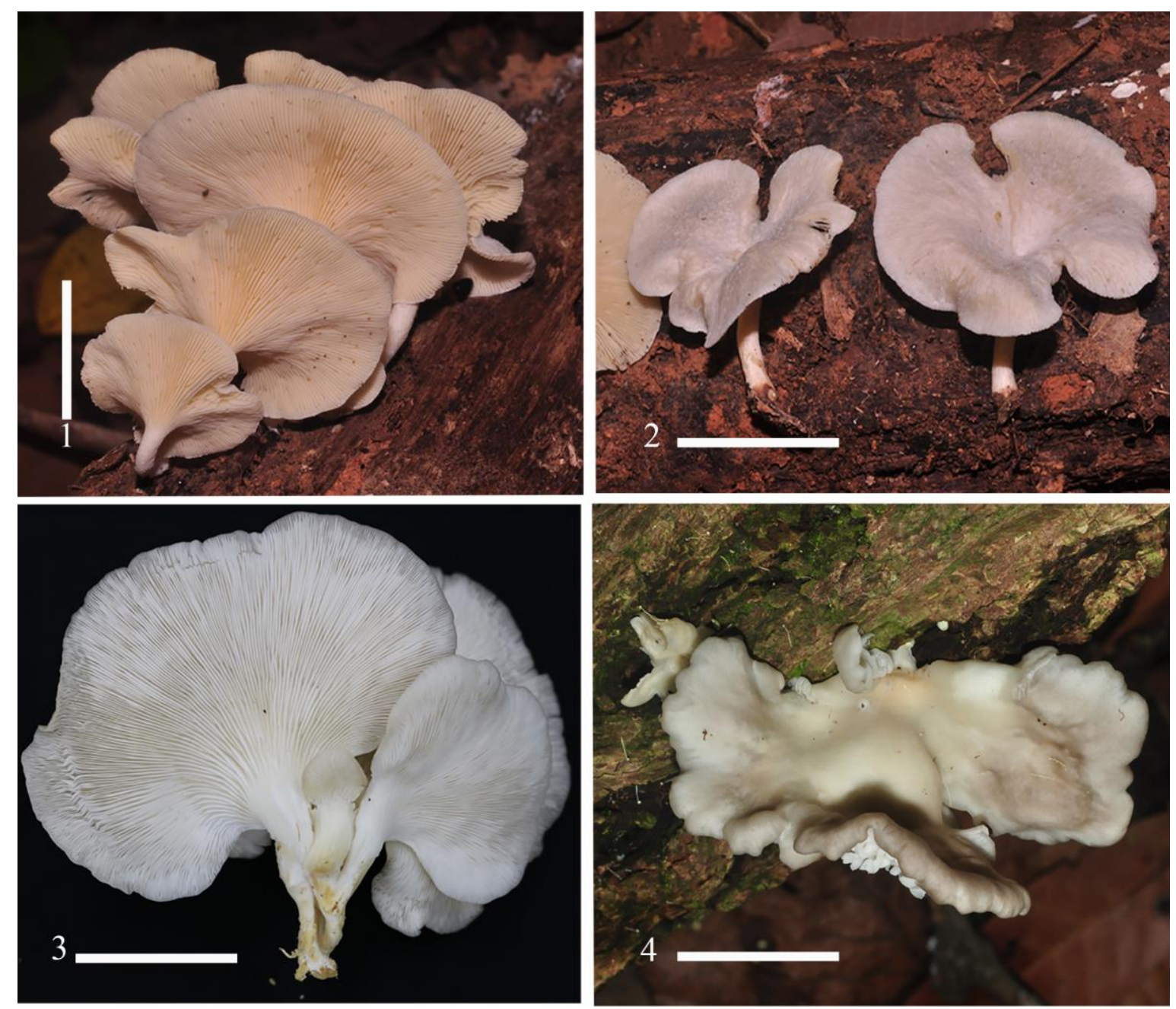

Fig. 1 - Comparison of morphlogical characteristics of lentinoid and pleurotoid mushrooms. 1, 2 Lentinoid mushrooms. 3, 4 Pleurotoid mushrooms. Scale bars $=5 \mathrm{~cm}$.

According to available data (Table 2), Lentinus sajor-caju have a highest protein content $(62.27 \pm 0.02 \mathrm{~g} / 100 \mathrm{~g})$, carbohydrate content $(68.24 \pm 0.22 \mathrm{~g} / 100 \mathrm{~g})$ and high energy content $(408.22 \pm$ $2.64 \mathrm{kcal} / 100 \mathrm{~g}$ ). The protein content is close to milk (6\%), eggs (26\%) and rice (5\%) (Source - U.S. Department of Agriculture, Agricultural Research Service. Food Data Central, 2019. fdc.nal.usda.gov). Hence, it could be considered as an alternative of protein source of Lentinus species have high carbohydrate content and low-fat content making them ideal ingredients to be included in the modern- 
day healthy diet. The most consumed species have not been reported yet as different countries have different preferences. For example, L. squarrosulus is popularly consumed as a food by local people in Africa (Lau \& Abdullah 2017) while L. sajor-caju is the most consumed and widely sold in the local Thai market (Karunarathna et al. 2011). For other species, it might be popular in local communities but there have been no such records yet. Lentinus squarrosulus has highest monosodium glutamate-like and sweet amino acids when compared with Hymenopellis superbiens (Berk.) R.H. Petersen and Naematelia aurantialba (Bandoni \& M. Zang) Millanes \& Wedin (Zhou et al. 2015). Species from this genus could be integrated in the daily diet as functional foods providing health-giving additives and medicinal benefits.

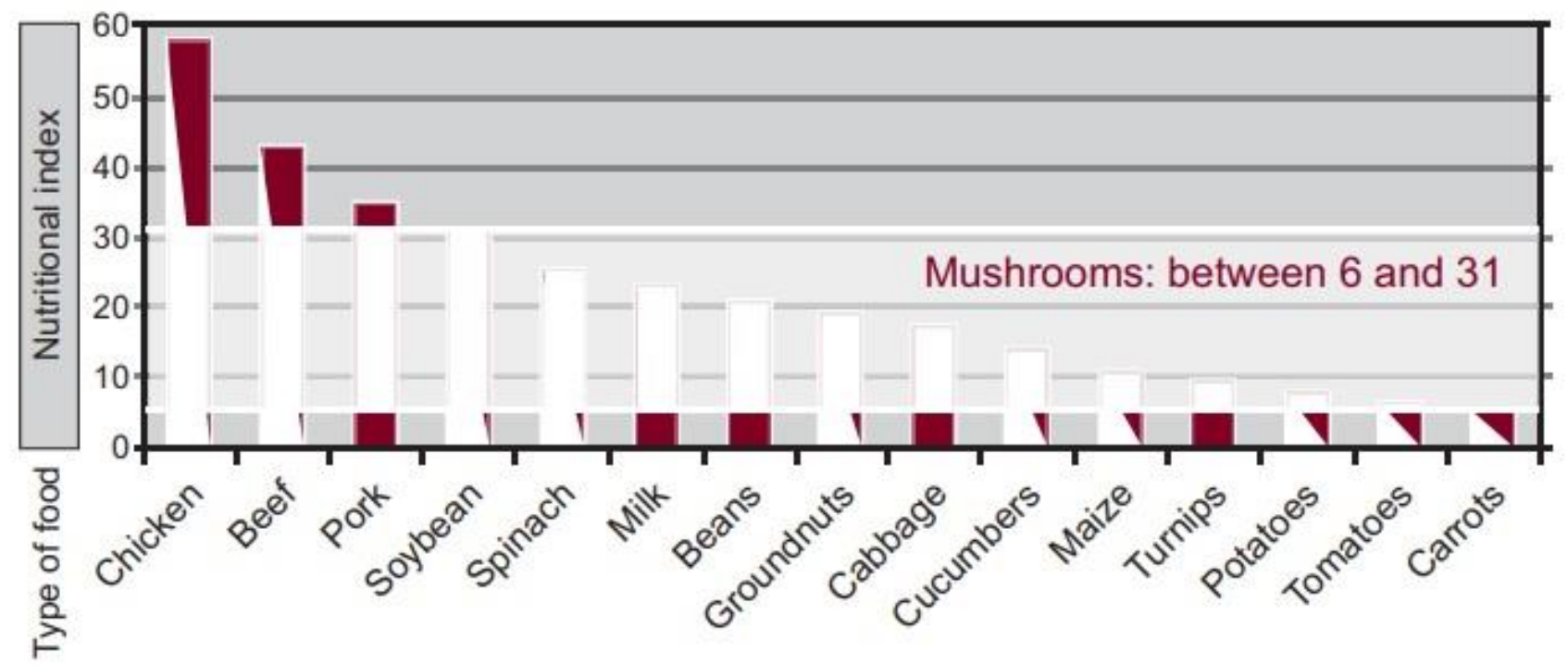

Fig. 2 - Comparison of the nutritional index of some important food as compared to mushrooms. Source - FAO. 2004 - Wild edible fungi, a global overview of their use and importance to people by Ferdousi et al. (2019).

\section{Cultivation of Lentinus species}

Mushroom production in the world has greatly increased, and there are many mushroom species have been widely cultivated which include Agaricus bisporus (J.E. Lange) Imbach (button mushrooms), Auricularia spp. (wood ear mushrooms), Flammulina velutipes (Curtis) (Enoki macrofungi), Lentinula edodes (Berk.) Pegler (shiitake), Pleurotus spp. (oyster mushrooms), and Volvariella volvacea (Bull.) Singer (straw mushrooms) (Reis et al. 2012, Ghosh 2020). Some mushrooms species are cultivated for their medicinal value which are Taiwanofungus camphoratus (M. Zang \& C.H. Su) Sheng H. Wu, Z.H. Yu, Y.C. Dai \& C.H. Su, Ganoderma spp. (Lingzhi mushroom), Tropicoporus linteus (Berk. \& M.A. Curtis) L.W. Zhou \& Y.C. Dai (black hoof mushroom) (Govorushko et al. 2019, Hyde et al. 2019). The factors affecting these mushrooms growth and cultivation include intrinsic factors and extrinsic factors. Both factors are affected by growing mushrooms. An extrinsic will impact the growth of the primarily basidiomes; and an intrinsic factor will impact the growth of the mycelium, the primordia formation and as well as the fruiting body development. To get a high mushrooms product, mushrooms cultivation needs the appropriate conditions and parameters based on the strain of the species (Mahari et al. 2020). Lentinus species are edible, but most of them are tough and leathery species (Karunarathna et al. 2011, Sharma 2014). The genus Lentinus comprises 55 species, but only some species have been cultivated such as L. crinitus, $L$. levis, L. polychrous, L. sajor-caju, L. squarrosulus, L. swartzii Berk and L. tigrinus. Previous studies 
have been done for e.g., suitable media, $\mathrm{pH}$, optimization temperature and evaluation of mushrooms yield, for the optimizing Lentinus cultivation. (Fasidi \& Kadiri 1993, Sobal et al. 1997, Okhuoya et al. 2005, Lechner \& Papinutti 2006, Lechner \& Albertó 2007, Salmones \& Gutierrez-Lecuona 2008, Ratanapongleka \& Phetsom 2014, Hussein et al. 2016, Conceição et al. 2017). In this review, we summarize methods of cultivation of Lentinus species consisting of different steps and methods from several studies; and the critical process, conditions, materials, and methods are provided in following steps:

\section{Mycelia culture condition}

The suitable growth conditions of mycelium of Lentinus have been optimized and evaluated on different solid and liquid media (Fasidi \& Kadiri 1993, Mensah \& Obodai 2014), and photos of good mycelial growths are showed in Fig. 3 (1). According to Dulay et al. (2012) and Dulay et al. (2017), it was reported that the mycelium of Lentinus grew well at $\mathrm{pH} 6.5-7.0$, and incubated at $30 \pm 2^{\circ} \mathrm{C}$ (room temperature) under dark condition. The formulation of chemically-defined culture media is determined by the nutritional requirements of Lentinus species. It was found that the mycelia favorably grew well on starch, fructose, sucrose, ammonium chloride, yeast extract and malt extract at $\mathrm{C} / \mathrm{N}$ ratio of 10:1, 10:1, and 40:1 (Dulay et al. 2020).

\section{Spawn type and preparation}

Spawn is an important factor in mushrooms production modern method of spawn preparation with cereal grains such as sorghum grain, wheat, millet, straw, coffee pulp, cotton waste and as well as sawdust. These materials can either be used alone or combined in different mixtures (Nwanze et al. 2005). No studies on the spawn optimization of Lentinus have been reported yet. The general spawn condition at which Lentinus species grow well is $25-32{ }^{\circ} \mathrm{C}$ (Kim et al 1994, Marim et al. 2018) in darkness condition for $2-3$ weeks for complete colonization. The good condition of spawn containing mycelium is provided in Fig. 3(2).

\section{Substrate types}

Lentinus species can grow in various substrates, specifically in lignocellulose waste. Lentinus species were successfully cultivated on sawdust (Okhuoya et al. 2005, Ayodele et al. 2007, Oghenekaro et al. 2009). There are five economic tropical tree species of sawdust namely, Brachystegia nigerica (okwen tree), Chlorophora excelsa (Sierra Leone, Liberia), Celtis sp. (hackberries or nettle trees), Guera cedrata (Bossy, Kwabohoro, Obobo) and Nesogordenia papaverifera (Kotibe, Kissinhungo, Danta) that have been reported suitable for cultivating Lentinus species. Furthermore, it can be cultivated with other materials such as cotton waste (Chang et al. 1981), barley straw (Sobal et al. 1997), paddy straw (Das et al. 2015), wood logs (Kadiri \& Halliru Arzai 2004), wheat straw (Lechner \& Papinutti 2006), bark and leaves of fruit trees (Adesina et al. 2011), and oil palm fruit fiber (Chiejina \& Osibe 2015). The additive is used for the cultivation of Lentinus include rice bran, wheat bran, sugar, calcium carbonate $\left(\mathrm{CaCO}_{3}\right)$, and calcium sulfate $(\mathrm{CaSO} 4)$. Moreover, composted and non-composted agricultural wastes have also been tested and used for the cultivation of Lentinus species. The yield of these mushrooms will be depended on the availability of nutrients in their environment. Therefore, if we want to improve biological efficiency, we should add nutrients supplements to substrate types. The unique nutritional requirements of each Lentinus species were suggested using the main material along with the required appropriate supplements and balance of carbon/nitrogen ratio in order to obtain extra yield (Okhuoya et al. 2005, Dulay et al. 2020). Furthermore, cultivations of Lentinus on logs of dead wood of the trees above are also considered by some local people, but scientific study of the yield value has not been reported. The photos of Lentinus products from sawdust substrate are in Fig. $3(5,8)$ and from logs are in Fig $3(4,6)$. 
Table 1 Potential bioactive compound and biological activities of some Lentinus species.

\begin{tabular}{|c|c|c|c|}
\hline Species name & Bioactive compound & Biological activities & References \\
\hline Lentinus crinitus (L.) Fr. & $\begin{array}{l}\text { } \beta \text {-tocopherol } \\
\text { Didehydro-1-desoxy-hypnophilinol A } \\
\text { Didehydro-1-desoxy-hypnophilinol B } \\
\text { Hypnophilol } \\
\text { Hypnophilin alcohol } \\
\text { Organic acids } \\
\text { Phenolic acids } \\
\text { P-hydroxybenzoic acid } \\
\text { Polysaccharides } \\
\text { 1-Desoxyhypnophilin } \\
\text { 1-Desoxyhypnophilol } \\
\text { 2,2-Dimethyl-6-methoxy-4- } \\
\text { chromanone } \\
\text { 2,2-Dimethyl-6-methoxy-4-chromanol } \\
\text { 6,7-Epoxy-4(15)-hirsutene-5-ol } \\
\text { 6,7-Epoxy-4(15)-hirsutene-1,5-diol } \\
\text { 6,7-Epoxy-4(15),8,8a-hirsutadien-5-ol } \\
\text { (S)-2,2-Dimethyl-3-hydroxy-6- } \\
\text { methoxy-4-chromanone }\end{array}$ & $\begin{array}{l}\text { Antitumor effects } \\
\text { Antimicrobial effects }\end{array}$ & $\begin{array}{l}\text { Abate \& Abraham (1994), Abrahanr \& } \\
\text { Abate (1995), López-Legarda et al. (2020), } \\
\text { Bertéli et al. (2021) }\end{array}$ \\
\hline L. cladopus Lév. & $\mathrm{N} / \mathrm{A}$ & Antimicrobial effects & Sudirman (2010) \\
\hline L. connatus Berk. & $\begin{array}{l}\text { Connatusin A } \\
\text { Connatusin B }\end{array}$ & $\mathrm{N} / \mathrm{A}$ & Rukachaisirikul et al. (2005) \\
\hline L. polychrous Lév. & 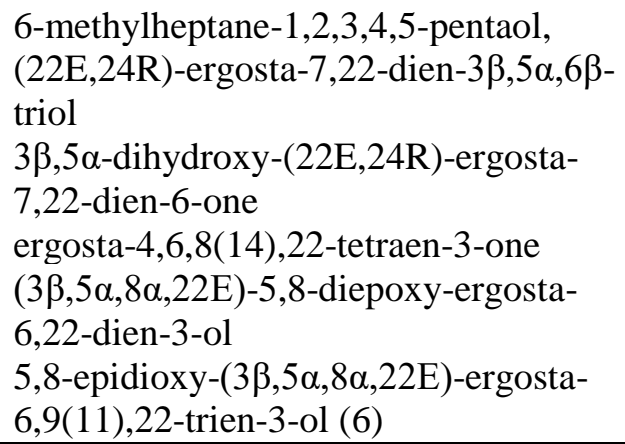 & $\begin{array}{l}\text { Antioxidant, } \\
\text { Anticancer } \\
\text { Cancer cell line cytotoxicity } \\
\text { Antiviral } \\
\text { Anti-inflammatory } \\
\text { Immunomodulatory effects }\end{array}$ & $\begin{array}{l}\text { Thetsrimuang et al. (2011), Fangkrathok et } \\
\text { al. (2013), Fangkrathok et al. (2021) }\end{array}$ \\
\hline
\end{tabular}


Table 1 Continued.

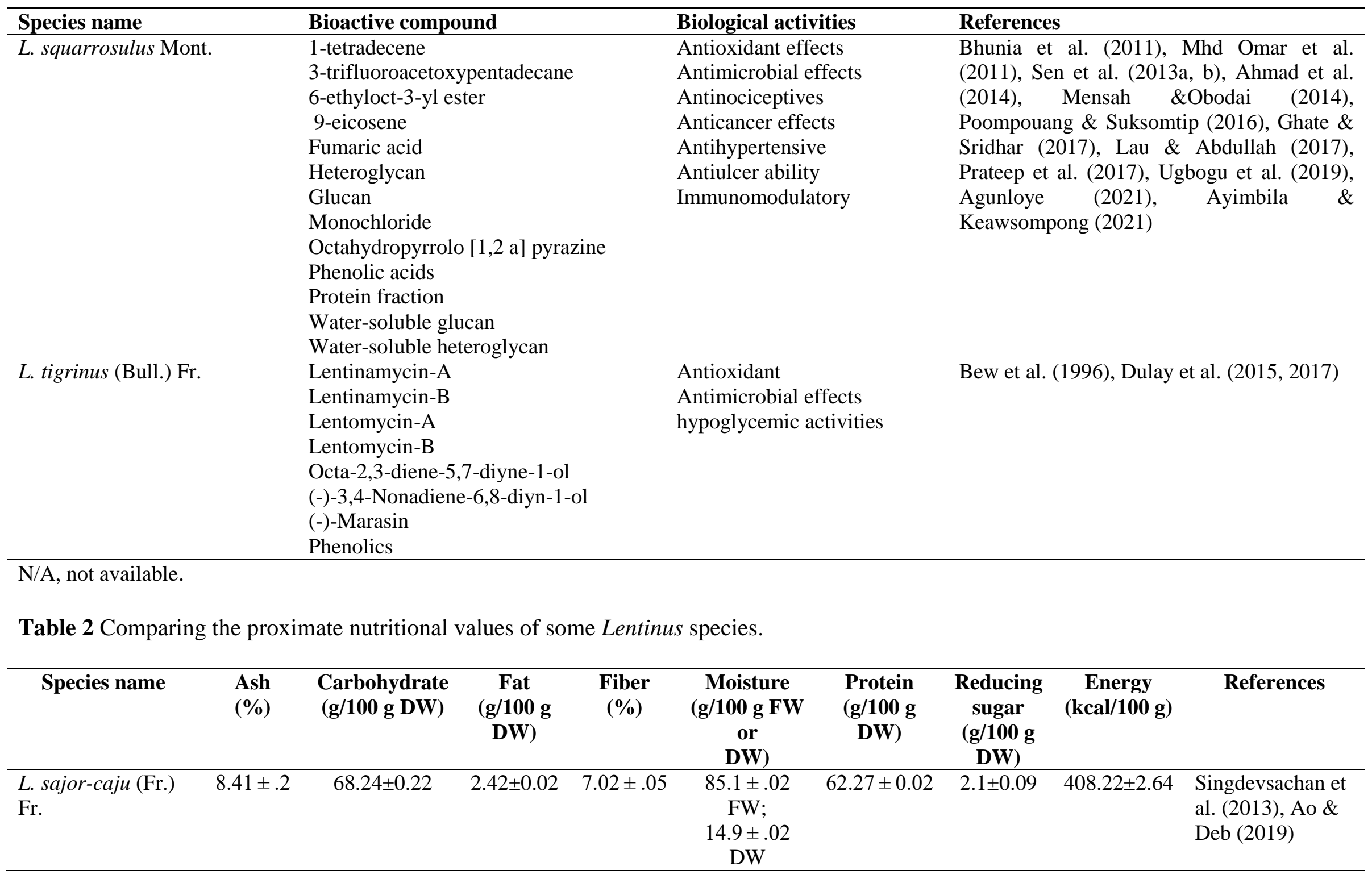


Table 2 Continued.

\begin{tabular}{|c|c|c|c|c|c|c|c|c|c|}
\hline Species name & $\begin{array}{l}\text { Ash } \\
(\%)\end{array}$ & $\begin{array}{l}\text { Carbohydrate } \\
\text { (g/100 g DW) }\end{array}$ & $\begin{array}{c}\text { Fat } \\
\text { (g/100 g } \\
\text { DW) }\end{array}$ & $\begin{array}{c}\text { Fiber } \\
(\%)\end{array}$ & $\begin{array}{c}\text { Moisture } \\
\text { (g/100 g FW } \\
\text { or } \\
\text { DW) }\end{array}$ & $\begin{array}{c}\text { Protein } \\
\text { (g/100 g } \\
\text { DW) }\end{array}$ & $\begin{array}{c}\text { Reducing } \\
\text { sugar } \\
\text { (g/100 g } \\
\text { DW) }\end{array}$ & $\begin{array}{c}\text { Energy } \\
(\text { kcal/100 g) }\end{array}$ & References \\
\hline $\begin{array}{l}\text { L. squarrosulus } \\
\text { Mont. }\end{array}$ & $10.66 \pm .4$ & $41.27 \pm 0.19$ & $6.76 \pm 0.22$ & $9.48 \pm 0.04$ & $\begin{array}{c}87.3 \pm .02 \\
\text { FW; } \\
12.7 \pm .02 \\
\text { DW }\end{array}$ & $42.77 \pm 0.57$ & $6.05 \pm .02$ & $342.35 \pm 3.0$ & $\begin{array}{l}\text { Ao \& Deb } \\
(2019), \text { Borokini } \\
\text { et al. }(2021)\end{array}$ \\
\hline $\begin{array}{l}\text { L. squarrosulus } \\
\text { var. squarrosulus } \\
\text { Mont. }\end{array}$ & $3.12 \pm .2$ & $19.14 \pm .01$ & $\mathrm{~N} / \mathrm{A}$ & $6.1 \pm .1$ & $\begin{array}{l}86.2 \pm .01 \\
\text { FW; } \\
13.8 \pm .01 \\
\text { DW }\end{array}$ & $18.77 \pm .02$ & $5.39 \pm .08$ & $\mathrm{~N} / \mathrm{A}$ & Ao \& Deb (2019) \\
\hline $\begin{array}{l}\text { L. tigrinus (Bull.) } \\
\text { Fr. }\end{array}$ & $3.41 \pm .2$ & $52.4 \pm 0.5$ & $2.1 \pm 0.4$ & $17.4 \pm 0.5$ & $\begin{array}{l}73.7 \pm .04 \\
\text { FW; } \\
26.3 \pm .04 \\
\text { DW }\end{array}$ & $31.85 \pm .03$ & $30.1 \pm 0.3$ & $\mathrm{~N} / \mathrm{A}$ & $\begin{array}{l}\text { Dulay et al. } \\
\text { (2014), Ao \& } \\
\text { Deb (2019) }\end{array}$ \\
\hline
\end{tabular}

FW, fresh weight; DW, dry weight; N/A, no data available. 


\section{Economical important}

Mushroom production has been increasing globally. In the world markets for the mushrooms, the industry has divided mushrooms into three types included edible mushrooms, medicinal mushrooms and wild mushrooms (Chang 2006). Mushrooms species have been integrated in many developing sectors in the food and nutraceutical industry further developing the market (Berch et al. 2007, Chang 2007, Zhang et al. 2014, Niego et al. 2021). More than 2,000 edible mushrooms species are widely accepted for human consumption, and have been documented to be used as food (Li et al. 2021). Mushroom is essential to the national economy in terms of mushroom production and generating income for local farmers. Cultivated mushrooms can be sold in both locally or exported to other countries to improve the country economy. With the increasing of quality of local product; the acceptance and demand for edible mushrooms have also significantly increased, and Lentinus species are consumed by many countries in Southeast Asia such as Laos (Tapingkae 2005, López-Legarda et al. 2020), Malaysia (Lee et al. 2009), Philippines (De Leon et al. 2013), Thailand (Pukahuta et al. 2008), Vietnam (Joly \& Perreau 1977), and in central part of Africa (Lau \& Abdullah 2017).
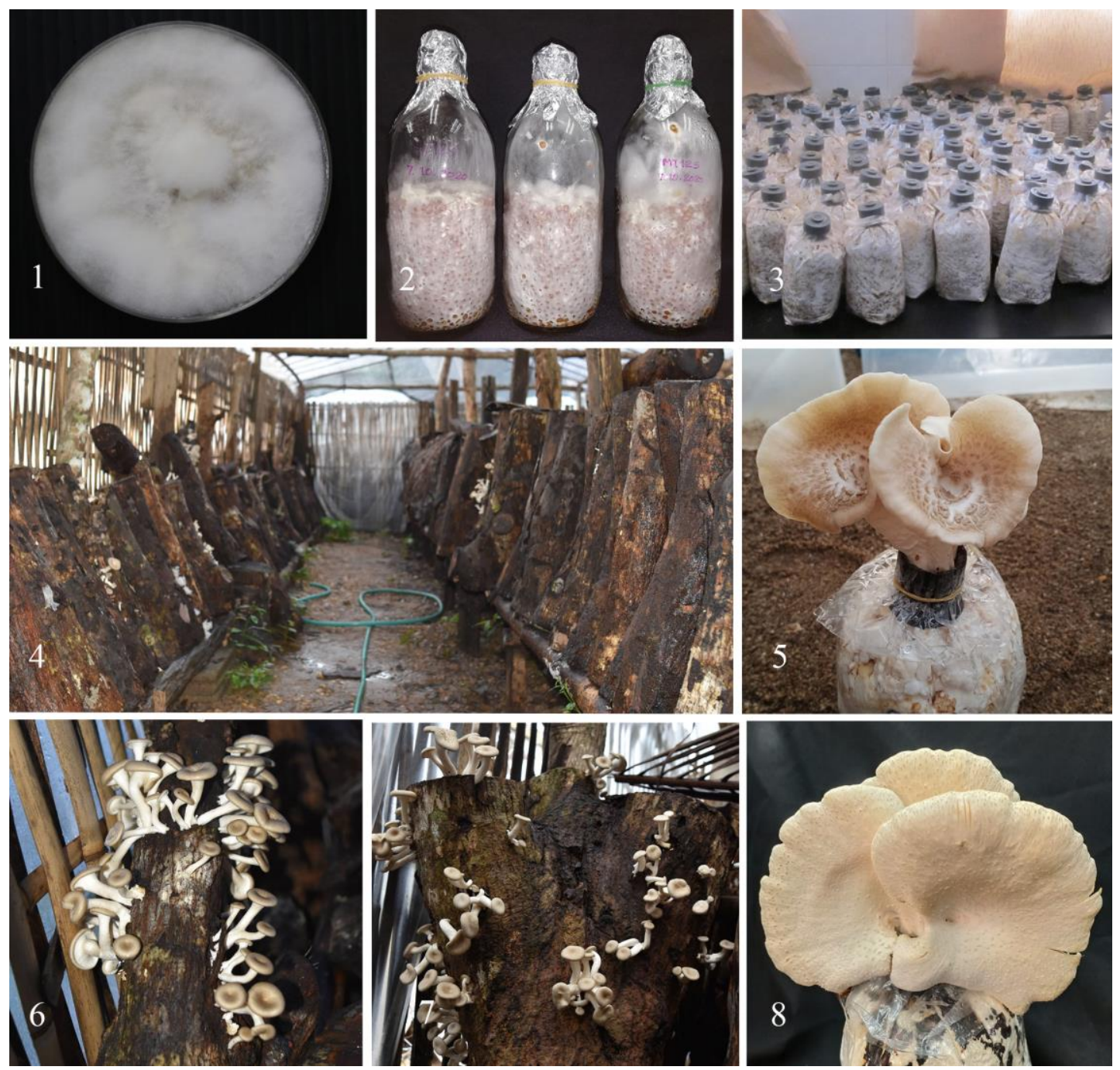

Fig. 3 - The cultivation process of Lentinus species. 1 Mycelium growth on solid media. 2 Spawn preparation on sorghum. 3 Mycelium growing on bag substrate. 4,6,7 Lentinus squarrosulus grows on logs. 5, 8 Lentinus squarrosulus grows on bag substrates.

Among of all commercially cultivated mushrooms, Lentinus species can be economically important mushrooms. Lentinus squarrosulus is the most cultivated species commonly found in both outdoor markets and supermarkets; and it is commercially cultivated using agricultural wastes 
to help the producers to reduce the cost of cultivation and increase profits. The price is around 120130 baht (TH.) per kilogram. Processed mushrooms are recommended to enhance the shelf life and modified to obtain a high price. The processing can be canned, dried, extract as medicinal or healthy drinks, and packed in frozen forms (Oddson \& Jelen 1981, Raman et al. 2018). Lentinus can be found as dried mushroom (Fig. 4), dried powder forms, fermented mushrooms in the local market. Therefore, cultivating Lentinus is suitable for farmers who start to cultivate mushrooms for commercial purposes. However, climate variability problems might cause negative effects for both the large-scale producers and small farmers, causing no mushrooms to enter the markets. Some mushrooms are considered to be effective in killing insect larva. Adeoye-Isijola et al. (2021), reported that activities of ethanol extract from the $L$. squarrosulus had insecticidal effects against the Aedes aegypti larva and pupa, having great potential as an alternative source of environmentally friendly insecticides. More importantly, Lentinus species are widely used in biotechnology and biochemical applications such as "bioremediation and delignification" (Bayramoglu et al. 2002, Arica \& Bayramoğlu 2007). The mycelia of L. sajur-caju could be considered as suitable biosorbents for the removal of cadmium in wastewater treatment systems (Bayramoglu et al. 2002), thus, reducing the cost of industrial wastewater treatment. From their potential benefits, Lentinus species could be important economical commodities.
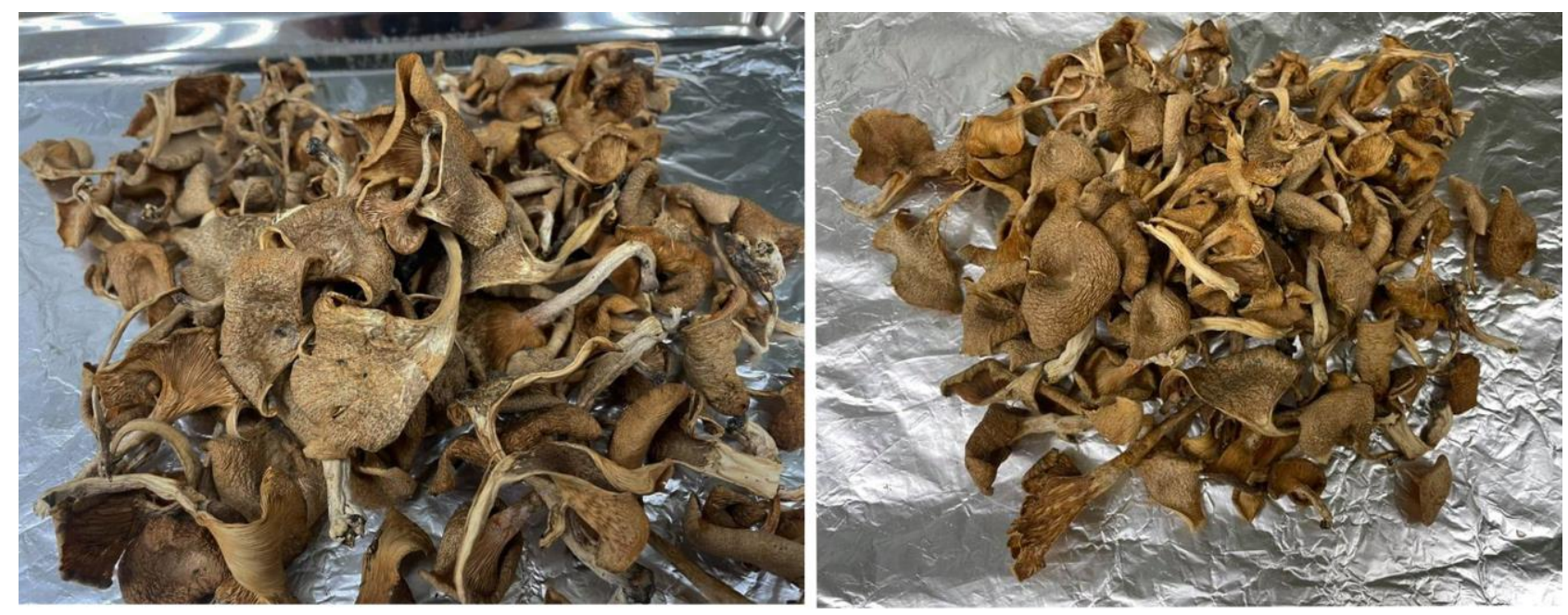

Fig. 4 - Processing of mushrooms, Lentinus squarrosulus as a dried form.

\section{Acknowledgements}

The authors would like to thank Thailand Science Research and Innovation (TSRI) grant "Macrofungi diversity research from the Lancang-Mekong Watershed and surrounding areas" (Grant No. DBG6280009) for funding.

\section{References}

Abate D, Abraham WR. 1994 - Antimicrobial metabolites from Lentinus crinitus. The Journal of Antibiotics 47, 1348-1350.

Abrahanr WR, Abate D. 1995 - Chromanones from Lentinus crinitus (basidiomycetes). Zeitschrift für Naturforschung C 50, 748-750.

Adenipekun CO, Isikhuemhen OS. 2008 - Bioremediation of engine oil polluted soil by the tropical white rot fungus, Lentinus squarrosulus Mont. (Singer). Pakistan Journal of Biological Sciences 11, 1634-1637.

Adeoye-Isijola MO, Jonathan SG, Coopoosamy RM, Olajuyigbe OO. 2021 - Molecular characterization, gas chromatography mass spectrometry analysis, phytochemical screening and insecticidal activities of ethanol extract of Lentinus squarrosulus against Aedes aegypti (Linnaeus). Molecular Biology Reports 48, 41-55. 
Adesina FC, Fasidi IO, Adenipekun OC. 2011 - Cultivation and fruit body production of Lentinus squarrosulus Mont. (Singer) on bark and leaves of fruit trees supplemented with agricultural waste. African Journal of Biotechnology 10, 4608-4611.

Agunloye OM. 2021 - Effect of aqueous extracts of Pleurotus ostreatus and Lentinus subnudus on activity of adenosine deaminase, arginase, cholinergic enzyme, and angiotensin-1-converting enzyme. Journal of Food Biochemistry 45, 13490.

Ahmad R, Muniandy S, Shukri NIA, Alias SMU et al. 2014 - Antioxidant properties and glucan compositions of various crude extract from Lentinus squarrosulus mycelial culture. Advances in Bioscience and Biotechnology 5, 805.

Anantharaju PG, Gowda PC, Vimalambike MG, Madhunapantula SV. 2016 - An overview on the role of dietary phenolics for the treatment of cancers. Nutrition journal 15, 1-16.

Akyüz M, KIRBAĞ S. 2010 - Nutritive value of edible wild and cultured mushrooms. Turkish Journal of Biology 34, 97-102.

Ao T, Deb CR. 2019 - Nutritional and antioxidant potential of some wild edible mushrooms of Nagaland, India. Journal of Food Science and Technology 56, 1084-1089.

Arica MY, Bayramoğlu G. 2007 - Biosorption of Reactive Red-120 dye from aqueous solution by native and modified fungus biomass preparations of Lentinus sajor-caju. Journal of Hazardous Materials 149, 499-507.

Atri NS. 2014 - Nutraceutical composition of wild species of genus Lentinus Fr. from Nothern India. Current Research in Environmental \& Applied Mycology 4, 11-32.

Ayimbila F, Keawsompong S. 2021 - Functional composition and antioxidant property of crude polysaccharides from the fruiting bodies of Lentinus squarrosulus. Biotech 11, 1-13.

Ayodele SM, Akpaja EO, Anyiador F. 2007 - Evaluation of the yield of Lentinus squarrosulus (Mont) singer on selected economic tree species. Pakistan Journal of Biological Sciences 10, 4283-4286.

Bayramoglu G, Denizli A, Bektas S, Arica MY. 2002 - Entrapment of Lentinus sajor-caju into Caalginate gel beads for removal of $\mathrm{Cd}$ (II) ions from aqueous solution: Preparation and biosorption kinetics analysis. Microchemical Journal 72, 63-76.

Berch SM, Ka KH, Park H, Winder R. 2007 - Development and potential of the cultivated and wild-harvested mushroom industries in the Republic of Korea and British Columbia. Journal of Ecosystems and Management 8, 53-75.

Bertéli MBD, Barros L, Reis FS, Ferreira IC et al. 2021 - Antimicrobial activity, chemical composition and cytotoxicity of Lentinus crinitus basidiocarp. Food \& Function 12, 6780 6792.

Bew RE, Chapman JR, Jones ER, Lowe BE et al. 1966 - Natural acetylenes. Part XVIII. Some allenic polyacetylenes from basidiomycetes. Journal of the Chemical Society C: Organic $129-135$.

Bhunia SK, Dey B, Maity KK, Patra S et al. 2011 - Isolation and characterization of an immunoenhancing glucan from alkaline extract of an edible mushroom, Lentinus squarrosulus (Mont.) Singer. Carbohydrate research 346, 2039-2044.

Binder M, Hibbett DS, Larsson K, Larsson E et al. 2005 - The phylogenetic distribution of resupinate forms across the major clades of mushroom-forming fungi (Homobasidiomycetes). Systematics and Biodiversity 3, 113-157.

Binder M, Justo A, Riley R, Salamov A et al. 2013 - Phylogenetic and phylogenomic overview of the Polyporales. Mycologia 105, 1350-1373.

Borokini F, Lajide L, Olaleye T, Boligon A et al. 2021 - Chemical profile and antimicrobial activities of two edible mushrooms (Termitomyces robustus and Lentinus squarrosulus). Journal of Microbiology, Biotechnology and Food Sciences 5, 416-423.

Carrasco J, Zied DC, Pardo JE, Preston GM, Pardo-Giménez A. 2018 - Supplementation in mushroom crops and its impact on yield and quality. AMB Express 8, 1-9.

Chang ST, Lau OW, Cho KY. 1981 - The cultivation and nutritional value of Pleurotus sajor-caju. European Journal of Applied Microbiology and Biotechnology 12, 58-62. 
Chang ST. 2006 - The world mushroom industry: trends and technological development. International Journal of Medicinal Mushrooms 8, 297-314.

Chang ST. 2007 - Development of the World Mushroom Industry and its roles in human health. Mushroom Biology and Biotechnology 213, 1-338.

Chang S, Wasser S. 2017 - The cultivation and environmental impact of mushrooms. Oxford University Press, New York.

Chiejina NV, Osibe DA. 2015 - Oil palm fruit fibre promotes the yield and quality of Lentinus squarrosulus (Mont.) Singer, an edible Nigerian mushroom. African Journal of Biotechnology 14, 1195-1200.

Conceição TA, Koblitz MGB, Kamida HM, Góes-Neto A. 2017 - Study of the production of Lentinus crinitus (L.) Fr. lignolytic enzymes grown on agro-industrial waste. Advances in Bioscience and Biotechnology 8, 259-272.

Corner EJH. 1981 - The agaric genera Lentinus, Panus and Pleurotus, with particular reference to Malaysian species. Nova Hedwigia Beihefte 69, 1-169.

Das AR, Borthakur M, Saha AK, Joshi SR et al. 2015 - Growth of mycelial biomass and fruit body cultivation of Lentinus squarrosulus collected from home garden of Tripura in Northeast India. Journal of Applied Biology \& Biotechnology 3, 17-19.

De Leon AM, Reyes RG, dela Cruz TEE. 2013 - Lentinus squarrosulus and Polyporus grammocephalus: Newly Domesticated, Wild Edible Macrofungi from the Philippines. Phil ippine Agricultural Scientist 96, 411-418.

Donk MA. 1964 - A conspectus of the families of Aphyllophrales. Persoonia - Molecular Phylogeny and Evolution of Fungi 3, 199-324.

Dulay RMR, Kalaw SP, Reyes RG, Cabrera EC et al. 2012 - Optimization of culture conditions for mycelial growth and basidiocarp production of Lentinus tigrinus (Bull.) Fr., a new record of domesticated wild edible mushroom in the Philippines. Philippine Agricultural Scientist 95, 278-285.

Dulay RMR, Arenas MC, Kalaw SP, Reyes RG et al. 2014 - Proximate composition and functionality of the culinary-medicinal tiger sawgill mushroom, Lentinus tigrinus (higher Basidiomycetes), from the Philippines. International Journal of Medicinal Mushrooms 16, 85-94.

Dulay RMR, Flores KS, Tiniola RC, Marquez DHH et al. 2015 - Mycelial biomass production and antioxidant activity of Lentinus tigrinus and Lentinus sajor-caju in indigenous liquid culture. Mycosphere 6, 659-666.

Dulay RMR, Garcia EJB. 2017 - Optimization and enriched cultivation of Philippine (CLSU) strain of Lentinus strigosus (BIL1324). Biocatalysis and Agricultural Biotechnology 12, 323 -328 .

Dulay RMR, Cabrera EC, Kalaw SP, Reyes RG et al. 2020 - Nutritional requirements for mycelial growth of three Lentinus species from the Philippines. Biocatalysis and Agricultural Biotechnology 23, 101506.

Eguchi F, Dulay RM R, Kalaw SP, Yoshimoto H et al. 2014 - Antihypertensive activities of a Philippine wild edible white rot fungus (Lentinus sajor-caju) in spontaneously hypertensive rats as models. Advances in Environmental Biology 8, 74-81.

Enas AE, Sabahelkhier MK, Malaz MM. 2016 - Nutritional composition and minerals content of five species of wild edible mushroom, brought from UAE: mushroom considered as protein source. International Journal of Advanced Research 4, 1108-1112.

Fangkrathok N, Sripanidkulchai B, Umehara K, Noguchi H. 2013 - Bioactive ergostanoids and a new polyhydroxyoctane from Lentinus polychrous mycelia and their inhibitory effects on E2enhanced cell proliferation of T47D cells. Natural Product Research 27, 1611-1619.

Fangkrathok N, Sripanidkulchai K, Junlatat J, Sripanidkulchai B. 2021 - Bioactivities of Lentinus polychrous and Ganoderma lucidum (Agaricomycetes) Polysaccharide Extracts. International Journal of Medicinal Mushrooms 23, 51-61. 
Fasidi IO, Kadiri M. 1993 - Use of agricultural wastes for the cultivation of Lentinus subnudus (Polyporales: Polyporaceae) in Nigeria. Revista de Biologia Tropical 41, 411-415.

Fernandes T, Garrine C, Ferrão J, Bell V et al. 2021 - Mushroom nutrition as preventative healthcare in sub-Saharan Africa. Applied Sciences 11, 4221-4247.

Ferdousi J, Al Riyadh Z, Hossain MI, Saha SR et al. 2019 - Mushroom production benefits, status, challenges and opportunities in Bangladesh: a review. Annual Research \& Review in Biology 34, 1-13.

Gbolagade JS, Fasidi IO, Ajayi EJ, Sobowale AA. 2006 - Effect of physico-chemical factors and semi-synthetic media on vegetative growth of Lentinus subnudus (Berk.), an edible mushroom from Nigeria. Food Chemistry 99, 742-747.

Ghasemzadeh A, Ghasemzadeh N. 2011 - Flavonoids and phenolic acids: Role and biochemical activity in plants and human. Journal of Medicinal Plants Research 5, 6697-6703.

Ghate SD, Sridhar KR. 2017 - Bioactive Potential of Lentinus squarrosulus and Termitomyces clypeatus from the Southwestern region of India. Indian Journal of Natural Products and Resources 8, 120-131.

Ghosh K. 2020 - A review on edible straw mushrooms: A source of high nutritional supplement, biologically active diverse structural polysaccharides. Journal of Scientific Research 64, 295304.

Govorushko S, Rezaee R, Dumanov J, Tsatsakis A. 2019 - Poisoning associated with the use of mushrooms: A review of the global pattern and main characteristics. Food and Chemical Toxicology 128, 267-279.

Grand EA. 2004 - Systematics and species concepts in the genera Lentinus Fr. and Panus Fr., with emphasis on the Lentinus tigrinus, L. crinitus and Panus lecomtei complexes. The University of Tennessee 1-116.

Grand EA, Hughes KW, Petersen RH. 2011 - Relationships within Lentinus subg. Lentinus (Polyporales, Agaricomycetes), with emphasis on sects. Lentinus and Tigrini. Mycological Progress 10, 399-413.

He MQ, Zhao RL, Hyde KD, Begerow D et al. 2019 - Notes, outline and divergence times of Basidiomycota. Fungal Diversity 99, 105-367.

Hibbett DS, Vilgalys R. 1991 - Evolutionary relationships of Lentinus to the Polyporaceae: evidence from restriction analysis of enzymatically amplified ribosomal DNA. Mycologia 83, 425-439.

Ho LH, Asyikeen Zulkifli N, Tan TC. 2020 - Edible mushroom: nutritional properties, potential nutraceutical values, and its utilization in food product development. London (UK): IntechOpen, 19-38.

Hussein JM, Tibuhwa DD, Mshandete AM, Kivaisi AK. 2016 - Successful domestication of Lentinus sajor-caju from an indigenous forest in Tanzania. Journal of Applied Biosciences 108, 10507-10518.

Hyde KD, Xu J, Rapior S, Jeewon R, et al. 2019 - The amazing potential of fungi: 50 ways we can exploit fungi industrially. Fungal Diversity 97, 1-136.

Joly P, Perreau J. 1977 - Sur quelques champignons sauvages consommés au Viet906 nam.Travaux-dedies a G.Vietnnot-Bourgin 159-168. (In French)

Jonathan SG, Fasidi IO. 2001 - Studies on phytohormones, vitamins and mineral element requirements of Lentinus subnudus (Berk) and Schizophyllum commune (Fr. Ex. Fr) from Nigeria. Food Chemistry 75, 303-307.

Kadiri M, Halliru Arzai A. 2004 - Cultivation of Lentinus subnudus Berk (Polyporales: Polyporaceae) on wood logs. Bioresource Technology 94.

Karunarathna SC, Yang ZL, Zhao RL, Vellinga EC et al. 2011 - Three new species of Lentinus from northern Thailand. Mycological Progress 10, 389-398.

Kim HK, Park JS, Cha DY, Kim YS et al. 1994 - Study on the artificial cultivation of Lentinus lepideus (Fr. ex Fr.) Fr. Investigation of Mycelial Growth Conditions. The Korean Journal of Mycology 22, 145-152. 
Kirk P, Cannon P, Stalpers J, Minter DW. 2008 - Dictionary of the Fungi.10th ed. CABI Publishing. Great Britain.

Largent DL. 1986 - How to identify mushrooms to genus vol. 1. Macroscopic features. Mad River Press, Eureka.

Lau BF, Abdullah N. 2017 - Bioprospecting of Lentinus squarrosulus Mont., an underutilized wild edible mushroom, as a potential source of functional ingredients: A review. Trends in Food Science \& Technology 61, 116-131.

Lechner BE, Papinutti VL. 2006 - Production of lignocellulosic enzymes during growth and fruiting of the edible fungus Lentinus tigrinus on wheat straw. Process Biochemistry 41, 594598.

Lechner BE, Albertó E. 2007 - Optimal conditions for the fruit body production of natural occurring strains of Lentinus tigrinus. Bioresource Technology 98, 1866-1869.

Lee SS, Chang YS, Noraswati MNR. 2009 - Utilization of macrofungi by some indigenous communities for food and medicine in Peninsular Malaysia. Forest Ecology and Management 257, 2062-2065.

Li H, Tian Y, Menolli Jr N, Ye L et al. 2021 - Reviewing the world's edible mushroom species: A new evidence-based classification system. Comprehensive Reviews in Food Science and Food Safety 20, 1982-2014.

López-Legarda X, Arboleda-Echavarría C, Parra-Saldívar R, Rostro-Alanis M et al. 2020 Biotechnological production, characterization and in vitro antitumor activity of polysaccharides from a native strain of Lentinus crinitus. International Journal of Biological Macromolecules 164, 3133-3144.

Mahari WAW, Peng W, Nam WL, Yang H et al. 2020 - A review on valorization of oyster mushroom and waste generated in the mushroom cultivation industry. Journal of Hazardous Materials 400, 123156.

Marim RA, Avelino KV, Linde GA, Colauto NB et al. 2018 - Lentinus crinitus strains respond differently to cultivation $\mathrm{pH}$ and temperature. Genetics and Molecular Research 17, 1-7.

Mensah DLN, Obodai M 2014 - Morphological characteristics of mycelia growth of two strains of the indigenous medicinal mushroom, Lentinus squarrosulus Mont. (Singer), on solid media. African Journal of Agricultural Research 9, 1753-1760.

Mhd Omar NA, Abdullah N, Kuppusamy UR, Abdulla M et al. 2011 - Nutritional composition, antioxidant activities, and antiulcer potential of Lentinus squarrosulus (Mont.) mycelia extract. Evidence-Based Complementary and Alternative Medicine 2011, 8.

Mohammadnejad S, Pourianfar HR, Drakhshan A, Jabaleh I et al. 2019 - Potent antiproliferative and pro-apoptotic effects of a soluble protein fraction from culinary-medicinal mushroom Lentinus tigrinus on cancer cells. Journal of Food Measurement and Characterization 13, 3015-3024.

Niego AG, Rapior S, Thongklang N, Raspé O et al. 2021 - Macrofungi as a Nutraceutical Source: Promising Bioactive Compounds and Market Value. Journal of Fungi 7, 397.

Nwanze PI, Khan AU, Ameh JB, Umoh VJ. 2005 - The effect of spawn grains, culture media, oil types and rates on carpophore production of Lentinus squarrosulus (Mont.) Singer. African Journal of Biotechnology 4, 478-482.

Oddson L, Jelen P. 1981 - Food processing potential of the oyster mushroom (Pleurotus florida). Canadian Institute of Food Science and Technology Journal 14, 36-41.

Oghenekaro AO, Okhuoya JA, Akpaja EO. 2009 - Growth of Lentinus squarrosulus (M.) Singer on sawdust of different tropical tree species. African Journal of Food Science 3, 7-10.

Qin DW, Gu Z, Guo JY. 2015 - Medicinal mushroom for prevention of disease of modern civilization. Evidence-Based Complementary and Alternative Medicine 2015, 2.

Okhuoya JA, Akpaja EO, Oghenekaro A. 2005 - Cultivation of Lentinus squarrosulus (Mont.) Singer on sawdust of selected tropical tree species. International Journal of Medicinal Mushrooms 7, 440-441. 
Oyetayo OV. 2011 - Medicinal uses of mushrooms in Nigeria: towards full and sustainable exploitation. African Journal of Traditional, Complementary and Alternative Medicines 8, 275-283.

Pegler DN. 1983 - The genus Lentinus: a world monograph. HMSO, London.

Poompouang S, Suksomtip M 2016 - Isolation and characterization of an antifungal peptide from fruiting bodies of edible mushroom Lentinus squarrosulus Mont. Malaysian Journal of Microbiology 12, 43-49.

Prateep A, Sumkhemthong S, Suksomtip M, Chanvorachote P et al. 2017 - Peptides extracted from edible mushroom: Lentinus squarrosulus induces apoptosis in human lung cancer cells. Pharmaceutical biology 55, 1792-1799.

Pukahuta C, Unphim U, Wuthikhamphee P, Payapanon A. 2008 - Biology and cultivation of Lentinus squarrosulus Mont. Thailand in: The International Society for Mushroom Science 17, 437-448.

Raman J, Lee SK, Im JH, Oh MJ et al. 2018 - Current prospects of mushroom production and industrial growth in India. Journal of Mushroom 16, 239-249.

Ratanapongleka K, Phetsom J. 2014 - Decolorization of Synthetic Dyes by Crude Laccase from Lentinus Polychrous Lev. International Journal of Chemical Engineering and Applications 5, 26.

Reis FS, Barros L, Martins A, Ferreira IC. 2012 - Chemical composition and nutritional value of the most widely appreciated cultivated mushrooms: an inter-species comparative study. Food and Chemical Toxicology 50, 191-197.

Roncero-Ramos I, Delgado-Andrade C. 2017 - The beneficial role of edible mushrooms in human health. Current Opinion in Food Science 14, 122-128.

Rukachaisirikul V, Tansakul C, Saithong S, Pakawatchai C et al. 2005 - Hirsutane Sesquiterpenes from the Fungus Lentinus connatus BCC 8996. Journal of Natural Products 68, 1674-1676.

Salmones D, Gutierrez-Lecuona MT. 2008 - Cultivation of Mexican Lentinus boryanus (Berk. et Mont.) Singer (Agaricomycetideae) strains on alternative substrates. International Journal of Medicinal Mushrooms 10, 73-78.

Seelan JSS, Justo A, Nagy LG, Grand EA et al. 2015 - Phylogenetic relationships and morphological evolution in Lentinus, Polyporellus and Neofavolus, emphasizing southeastern Asian taxa. Mycologia 107, 460-474.

Seelan JSS. 2015 - Systematic study of Lentinoid and Pleurotoid mushrooms (Basidiomycota) of South East Asia. Clark University.

Sen IK, Maji PK, Behera B, Maiti TK et al. 2013a - Glucan of a somatic hybrid mushroom, pfls1h: structural characterization and study of immunological activities. International Journal of Biological Macromolecules 53, 127-132.

Sen IK, Maji PK, Behera B, Mallick P et al. 2013b - Structural characterization of an immunoenhancing heteroglycan of a hybrid mushroom (pfls1h) of Pleurotus florida and Lentinus squarrosulus (Mont.) Singer. Carbohydrate Research 371, 45-51.

Senthilarasu G. 2015 - The Lentinoid fungi (Lentinus and Panus) from Western Ghats, India. IMA Fungus 6, 119-128.

Sevindik M. 2018 - Investigation of antioxidant/oxidant status and antimicrobial activities of Lentinus tigrinus. Advances in Pharmacological Sciences 2018, 4.

Sharma S. 2014 - Nutraceutical composition of wild species of genus Lentinus Fr. from Northern India. Current Research in Environmental \& Applied Mycology 4, 11-32.

Singer R. 1986 - The Agaricales in modern taxonomy. 4th ed. Koenigstein, Germany. Koeltz Scientific Books, 981.

Singdevsachan SK, Patra JK, Thatoi H. 2013 - Nutritional and bioactive potential of two wild edible mushrooms (Lentinus sajor-caju and Lentinus torulosus) from Similipal Biosphere Reserve, India. Food Science and Biotechnology 22, 137-145.

Sobal M, Morales P, Martínez W, Pegler DN et al. 1997 - Cultivation of Lentinus levis in Mexico. Micologia Neotropical Aplicada (Mexico) 10, 63-71. 
Sudirman LI. 2010 - Partial purification of antimicrobial compounds isolated from mycelia of tropical Lentinus cladopus LC4. HAYATI Journal of Biosciences 17, 63-67.

Sysouphanthong P, Thongkantha S, Zhao R, Soytong K et al. 2010 - Mushroom diversity in sustainable shade tea forest and the effect of fire damage. Biodiversity and Conservation 19, 1401-1415.

Tapingkae T. 2005 - Mushroom growers' Handbook 2, Shiitake Cultivation, Part II Mushroom for Better Life. Regional Studies: Mushroom growing in Lao PDR 244-259.

Thetsrimuang C, Khammuang S, Chiablaem K, Srisomsap C et al. 2011 - Antioxidant properties and cytotoxicity of crude polysaccharides from Lentinus polychrous Lév. Food Chemistry $128,634-639$.

Ugbogu EA, Akubugwo IE, Ude VC, Gilbert J et al. 2019 - Toxicological evaluation of phytochemical characterized aqueous extract of wild dried Lentinus squarrosulus (Mont.) mushroom in rats. Toxicological Research 35, 181-190.

Valverde ME, Hernández-Pérez T, Paredes-López O. 2015 - Edible mushrooms: improving human health and promoting quality life. International journal of Microbiology 2015, 14.

Zhang Y, Geng W, Shen Y, Wang Y et al. 2014 - Edible mushroom cultivation for food security and rural development in China: bio-innovation, technological dissemination and marketing. Sustainability 6, 2961-2973.

Zhou S, Tang Q, Zhang Z, Li CH et al. 2015 - Nutritional composition of three domesticated culinary-medicinal mushrooms: Oudemansiella sudmusida, Lentinus squarrosulus, and Tremella aurantialba. International journal of medicinal mushrooms 17, 43-49. 